BRONWYN H. HALL

University of California, Berkeley

ROBERT E. HALL

Stanford University

\title{
The Value and Performance of U.S. Corporations
}

THE VALUE OF A CORPORATION is known from hour to hour in the stock market. The performance of a corporation, from the shareholders' perspective, is measured by the corporation's ability to pay dividends, now and in the indefinite future. Our research investigates the relation between value and performance. We use modern finance theory as a benchmark for valuation. Finance theory holds that, on average, the current value of a share is the discounted value of the future dividends the share earns. The theory is explicit about the discount rate. If, on average, over firms and over time, shares sell for less than the discounted value of the dividends the shares ultimately pay, it means that the stock market undervalues those shares; investors require a higher rate of return than theory suggests they should.

Our motivation for this research is the persistent criticism that American capitalism, with its focus on stock prices determined by myopic investors, diverts managers from efficient, long-term investments toward the style of management most pleasing to the stock market. We ask if certain managerial decisions or firm characteristics result in stock prices that are higher or lower than the benchmark provided by finance theory. Is the market systematically shortsighted with respect to all activities, placing too little value on deferred payoffs? Did this problem worsen

We are grateful to Chris Hall for assistance and to the Econometrics Laboratory at University of California, Berkeley, for massive computations. This research was supported in part by the National Science Foundation. We benefited enormously from the comments of the discussants and others at the Brookings Panel meeting. 
during the 1980s? Does the market favor higher current accounting earnings? Does it put a higher value on firms that invest in plant and equipment? Does it put a lower value on firms that invest in research and development (R\&D), advertising, and other forms of intangible, difficult-to-value capital? Does it put a higher value on firms that pay high dividends? All of these are claims made by the critics of American capitalism.

If the answer is yes to any of these questions, there is an unexploited opportunity for arbitrage in the U.S. stock market. For example, if the market undervalues firms that follow a Japanese-style strategy of high investment in product design and market penetration, then an investor can beat the market by investing in these firms for the long term, deriving high net value after ten or more years of holding the shares until the payoff becomes apparent to other investors. Central to the critique of American capitalism is the absence of patient arbitrageurs with decade-long buy-and-hold strategies. The whole focus of the professional money managers who dominate shareholdings in the United States is on arbitrage strategies with payoffs in minutes, hours, or at most months, say the critics.

Our findings give strong but partial support to the critique. We find statistically unambiguous evidence of important arbitrage profits from long-term strategies. Three of our findings favor the critique.

First, the stock market is systematically shortsighted; it favors policies that generate near-term dividends over those that require waiting. All investors who place their funds in the stock market rather than in the bond market earn large extra rewards over time after consideration of the relative riskiness of stocks and bonds. This finding confirms earlier well-known results on the equity premium puzzle. ${ }^{1}$ Second, although the bias against deferred payoffs lowers the incentive for investment of all types, the bias is smaller for investment in plant and equipment than for investments in intangibles. Third, the market disfavors intangible investment in advertising.

On the other hand, we make three findings unfavorable to the critique. First, the market puts a lower value on firms with higher book earnings, after standardizing for actual subsequent performance. In other words, the patient arbitrageur can make money by buying firms 
with unusually high reported current earnings and holding them until subsequent performance shows that the market erred by placing such a low value on these firms. Second, the market puts a higher value on $\mathrm{R} \& \mathrm{D}$ investment than is warranted by subsequent performance. The patient arbitrageur comes out ahead by avoiding R\&D-intensive firms. (This finding is at a lower level of statistical confidence than the previous ones.) And third, excess discounts fell in the 1980s relative to the 1970s.

Our work looks at the values of the shares of a sample containing about half the publicly traded U.S. manufacturing corporations from 1964 through 1991. Within the framework of modern finance theory, we study the relation between share value and actual subsequent payouts to shareholders. Our approach is an application of the general principles developed in Robert Hall's work with Steven N. Durlauf. ${ }^{2}$ The approach permits us to make rigorous statements about departures of share prices from the level mandated by valuation theory and to associate those departures with particular characteristics of firms. Although our approach puts a predicted fundamental value on each firm in our sample for each year, these valuations are quite noisy. We reach stronger conclusions by looking at statistical averages of the difference between stock prices and fundamental values over many stocks and many years, which eliminates most of the noise.

Our work is a departure from the abundant recent literature on valuation anomalies. ${ }^{3}$ That literature shows that such a thing as an undervalued firm exists. The findings result from a search for the most successful current variables for forecasting later performance. The best forecasting variables are invariably ratios with the current stock price in the denominator. Thus the character of the findings is that investment in stocks with high earnings-price ratios, high dividend-price ratios, or high book value-price ratios will earn abnormally high returns. The researchers in this tradition advocate value strategies and have impressive evidence that such strategies earn high returns when applied in the real world. In contrast, we take as given that such a thing as an undervalued firm exists. We are interested in describing the association of undervaluation with the choices made by the firm's managers. For example, we are inter-

2. Durlauf and R. Hall (1990).

3. Basu (1977), De Bondt and Thaler (1985), Fama and French (1988), and Lakonishok, Shleifer, and Vishny (1993) are leading contributions. Scott (1985) shows the same thing in the framework of Shiller (1981) and LeRoy and Porter (1981). 
ested in measuring the undervaluation of firms with policies of heavy investment in plant and equipment. To achieve this objective, we must exclude the current stock price from our right-hand variables. It would be uninteresting in our framework to conclude that firms with low stock prices suffer high discounting in the stock market, even though the stock-picking rule that tells the investor to look for low stock prices generates the highest expected returns. Our work is not a contribution to the finance literature showing that valuation anomalies exist. Rather, we apply the methods of finance in a new way to consider the issues raised by the critics of the stock market.

A second important warning to the reader is that our research deals with the external valuation of the firm. We can comment on how the stock market responds to the observable variables as they are determined by the firm's managers. We cannot comment on the internal responses to the valuation errors made by the stock market. For example, we show that the market is shortsighted with respect to investment; it puts a discount higher than the one merited by finance theory on the subsequent earnings from a capital project. We presume, but we do not show, that managers respond by launching too few capital projects with deferred payoffs. Our work deals with stock market myopia, not corporate myopia. Of the two major elements of the case that capitalism is shortsighted, we consider only one.

The restriction to issues of external valuation brings clarity to our work, we believe. Other approaches have to deal with conflicting internal and external influences. For example, Michael Jensen has argued that the tendency for a firm's share price to jump when the firm announces an investment project is a sign that the stock market is not myopic, and so managers driven by stock market incentives should not behave myopically. ${ }^{4}$ But Jeremy Stein observed that the finding is hardly dispositive. ${ }^{5}$ In his model, managers behave myopically in equilibrium. They set a hurdle rate above the market's discount rate, so the adoption of a project generates a positive gain for the shareholders precisely because of myopia.

Our approach in this paper is complementary to the approach taken by Bronwyn Hall in previous work. ${ }^{6}$ She has studied the relation be-

4. Jensen (1988). He cites the event study of McConnell and Muscarella (1985).

5. Stein (1989).

6. B. Hall $(1992,1993 a)$. 
tween the current reproduction cost of a firm's hardware and software capital (plant and equipment, inventories, ownership of other firms, R\&D capital, and advertising capital) and the total value of the firm's debt and equity. She estimates an overall Tobin's $q$, the ratio of the market value of debt and equity to the reproduction cost of the firm's assets. This measure changes sharply over time, in line with previous findings. Novel in her work is a set of estimates of the premiums or discounts in the valuation of different types of capital relative to plant and equipment. Over the period 1973-91, she finds that inventories, equity in other firms, and the intangibles that appear on the balance sheet all enjoy stock market premiums over plant and equipment. R\&D capital is valued at a discount of approximately 50 percent over the entire period; the discount changes sharply in the early 1980 s from around 30 percent to roughly 80 percent. Although the value of the discount is sensitive to the depreciation rate used in constructing R\&D capital, implausibly high depreciation rates (greater than 50 percent per year) would be required to place $R \& D$ capital on an equal footing with plant and equipment in this framework. On the other hand, she finds that, during the same period, the market value of advertising spending rose from zero to parity.

Examination of the market value of the firm's assets has the important advantage that the results can be brought right up to date. Our method in this paper requires us to wait until the firm actually makes use of its assets to generate earnings and thus dividends. On the other hand, we can ask a sharper question because we look only at the external valuation. A finding that a particular type of asset suffers a discount in the stock market could tell us that we measured the asset incorrectly, that managers are investing in the asset even though the market knows that the investment will be unproductive, or because the market is shortsighted about the eventual payoff from the investment. Our approach in this paper focuses cleanly on only the last issue.

\section{The Benchmark of Finance Theory: Theoretical Framework and Example}

Our framework examines the relation between the price of a share and the payouts made by a corporation to the holder of the share. The owner of a share can influence the time pattern of the payouts by choos- 
ing a time to sell. In addition, corporations sometimes pay dividends by issuing additional shares to existing shareholders. We assume that all shareholders are indifferent between selling and retaining shares at all times, so that we can examine valuation under standardized assumptions about the time pattern of payouts. In so doing, we ignore habitat effects that arise from differences in tax rates and other sources of shareholder heterogeneity; these habitat effects will be part of the noise in our valuation equation (surely a very small fraction).

We will explain our theoretical framework informally, using an example based on the Standard and Poor's (S\&P) 500 portfolio. Appendix A presents the technical version of the framework.

Robert Shiller and, simultaneously and independently, Stephen LeRoy and Richard Porter, introduced the idea of relating the market value of a stock to the present discounted value of its actual later dividends. ${ }^{7}$ They exploited statistical restrictions based on the principle that the later realization differs from the market expectation when the price is determined by an expectation error. Their main point was that an expectation or forecast must have less variance than the ultimate realization. Simple calculations for stock market indexes suggested that this variance inequality failed by a large margin, and Shiller and LeRoy-Porter interpreted the failure as a sign that the market did not adhere to the principle that the market value of a stock is the present discounted value of its dividends. ${ }^{8}$

Our approach moves in the direction of a structural model of the stock market's valuation of a firm. In the tradition of Shiller and LeRoy-Porter, we find a discrepancy between the actual price of a stock and the price the stock should be, given a simple financial valuation model, but we go on to build a more elaborate model that eliminates the discrepancy. We basically make two kinds of elaborations. One is to use discounting formulas that are closer to the exact prescriptions of modern finance theory. The earliest literature assumed a discount rate that was constant over time and over maturity. We use discounts derived from data on U.S. Treasury securities that vary from year to year and do not have a flat term structure. With respect to discounting, we also explore the risk premiums suggested by finance theory.

7. Shiller (1981) and LeRoy and Porter (1981).

8. See Gilles and LeRoy (1991) for a discussion of the huge literature that followed the two original papers. 
Figure 1. The S\&P 500 Stock Price Index and the Risk-free Present Discounted Value of Its Future Dividends

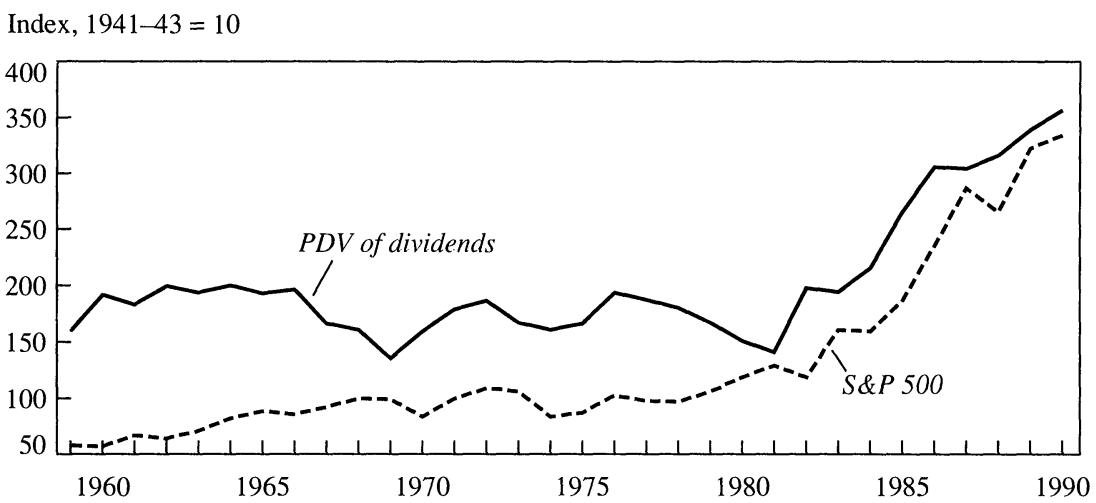

Source: Economic Report of the President, 1992, table B-91.

The second type of elaboration is to characterize departures of market values from financial valuation formulas in terms of the observed characteristics of firms. We find that the market tends to use higher discount rates for firms with unusually high earnings and tends to use lower discounts for firms with unusually high R\&D spending, unusually high investment in plant and equipment, or unusually high debt.

We look for effects on discount rates, rather than on the level of the market value of a firm. That is, our findings are of the sort, "A firm that raises its investment by 10 percentage points in relation to assets lowers its discount rate by 1 percentage point" rather than "A firm that raises its investment by 10 percentage points raises its market price in relation to the present value of its future dividends by 15 percent." The reason is simple. Many of the firms in our sample make a terminal payment to their shareholders within a year or two of the time we are looking at their share price. The main source of these terminal payments is takeovers. In addition, we take the 1991 share price as a terminal payment for firms surviving to the end of our sample period. Especially in the latter case, we would not expect the same ratio of theoretical to actual value to apply when the terminal payment is just around the corner as when it is in the distant future.

Figure 1 shows this point clearly. We compare the actual level of the S\&P 500 stock price index to the present value of actual future divi- 
Figure 2. Value Shortfall for the S\&P $5_{00}{ }^{a}$

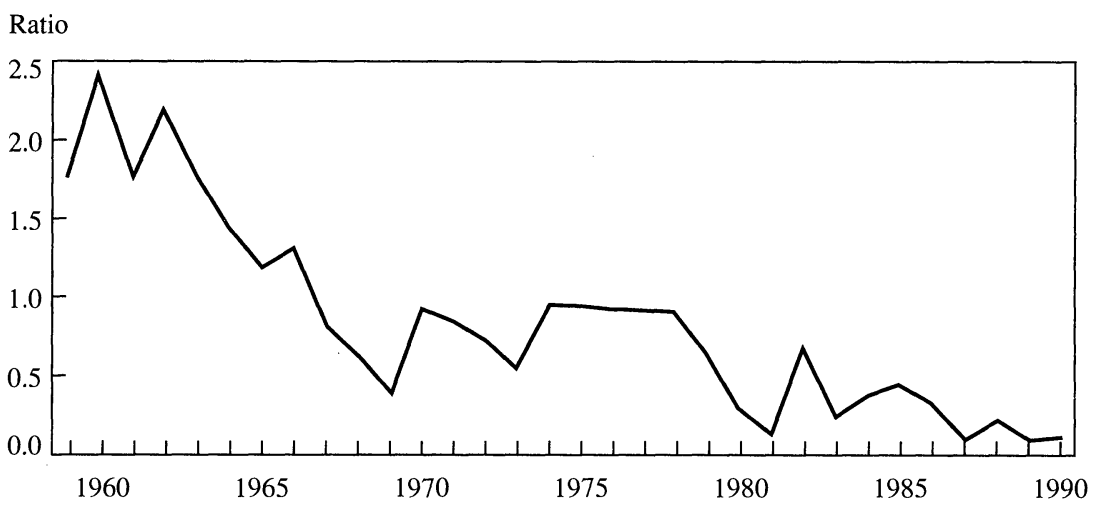

Source: See figure 1 .

a. The value shortfall is the difference between the discounted present value of future dividends and the index price, divided by the index price. See the text for details.

dends, discounted by the risk-free discounts implicit in the Treasury securities market. ${ }^{9}$ The actual value of the index in 1991 is taken as the terminal dividend. Two features are immediately apparent from figure 1. First, the actual market is generally far below the present value of subsequent dividends; the ratio of theoretical to actual reaches a peak of close to 4 during the early 1960s. Second, the gap disappears as the terminal date approaches. The average ratio of theoretical to actual value would not be an interesting characterization of the discrepancy between the two.

Figure 2 plots a measure we call $z$, the value shortfall. It is the difference between the present value of future dividends, $d_{\tau}$, discounted by $R_{t, \tau}$, and the index price, $p_{t}$, divided by the index price,

$$
z_{t}=\frac{\sum_{\tau=t+1}^{T} R_{t, \tau} d_{\tau}-p_{t}}{p_{t}}
$$

where $t$ is the year of valuation, as of the end of the year, $\tau$ is the year of future payout, and $T$ is the terminal year, either 1991 or the last year traded.

If theory and reality agreed perfectly, the value shortfall would be an unpredictable surprise that averaged zero. Instead, as in figure 2 , the

9. Taken from Coleman, Fisher, and Ibbotson (1989). 
value shortfall is always positive, and the shortfall declines to zero as the terminal date approaches. A higher discount rate in the calculation of the present value of dividends could reduce the value shortfall in the right way; the downward effect would be greater in the earlier years. Our method is to infer the excess discount rate from the value shortfall by choosing a rate that makes the shortfall as small as possible. One econometric issue needs attention. Because the value shortfall is calculated from the actual future dividends, we cannot use ordinary least squares as the criterion for a small shortfall. Instead, we use nonlinear two-stage least squares. ${ }^{10}$ That is, we use instrumental variables known at time $t$, and thus uncorrelated with the expectation errors, to measure the magnitude of the value shortfall. Specifically, our criterion is the sum of squared residuals from the regression of the value shortfall on the instrumental variables.

Our procedure is then simply to regress the value shortfall on the instruments, with a correction for serial correlation (explained further in appendix B), for different discounts until we find the discount that makes the regression have its lowest explanatory power. Standard econometric methods permit us to recover the standard error of the estimate of the extra discount. For the S\&P 500, we use only the constant as the instrument. The econometric procedure then boils down to finding the value of the extra discount that makes the sum of the value shortfalls equal zero. That value is 0.0426 , with a standard error of 0.0032 . The procedure indicates that the discount rate should be 4.26 percentage points higher than the risk-free discount used in the calculations for figure 1.

Finally, figure 3 repeats the comparison of the actual value of the S\&P 500 stock price index and the present value of its future dividends, using the estimated extra discount. Most of the problems of figure 1 are solved; it is not obvious that the discrepancies are not simply the result of expectation errors about future dividends; for example, the market may have been a little optimistic in the late 1960 s and a little pessimistic in the late 1970s.

Figure 3 is about as far as we can go with pure time-series evidence. Our main research makes use of a rich panel of data on the majority of publicly traded manufacturing firms in the United States. The cross-sec- 
Figure 3. The S\&P 500 and the Fully Discounted Present Value of Its Future Dividends ${ }^{a}$

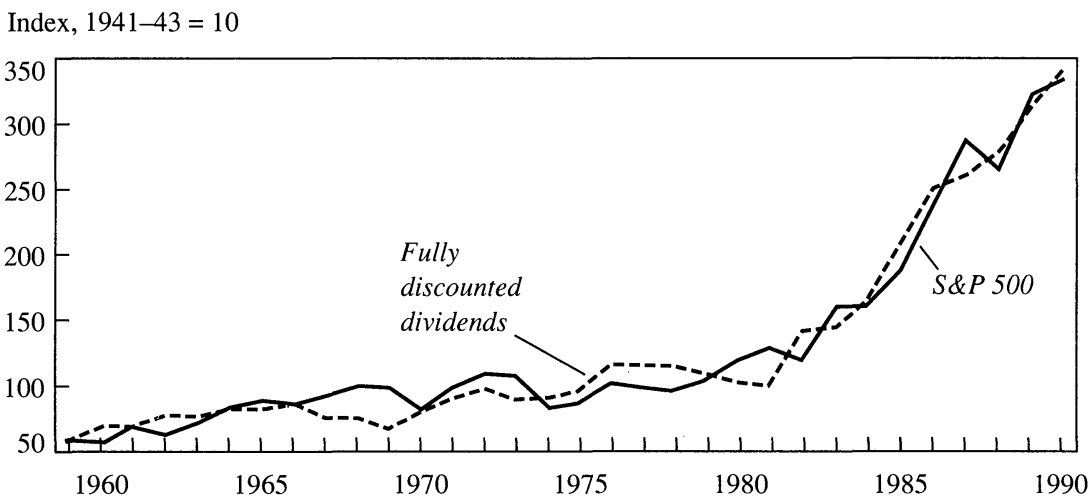

Source: See figure 1.

a. Figure 3 is similar to figure 1, except that the fully discounted present value of future dividends is discounted at a higher rate to minimize the shortfall. See the text for details.

tion dimension allows us to associate valuation discrepancies with observed characteristics of firms. For example, one of our findings is that the market places a higher value (that is, uses a lower discount) on the dividends of firms with high ratios of investment to total book assets. To reach this conclusion, we use a specification that makes the extra discount depend linearly on the investment-assets ratio. We also use instrumental variables that are derived from the investment-assets ratio. The effect of this specification is to assign a higher discount rate to firms with higher investment-assets ratios, if the coefficient of the variable is positive. As it happens, the coefficient is $\mathbf{- 7 . 8 4}$ with a standard error of 1.78 . The interpretation is that firms with more investment get lower dividend discounts in the stock market, and thus higher market values. A firm with 10 percentage points more investment in relation to assets has a discount rate that is 0.784 percentage points lower.

We have already noted that we view many of our firms as making terminal payouts to their shareholders before the end of our sample period in 1991. Our valuation method is based on a particular strategy of a representative shareholder about when to sell. Our specific assumptions are that the shareholder keeps his or her shares, including all dividends paid in shares, and that our hypothetical shareholder takes all cash dividends as payouts. With respect to tender offers, we proceed in the following way: If the shares of a corporation continue to be traded after a tender 
offer, our hypothetical shareholder does not sell to the tenderer. Dividends from the new shares are treated as dividends from the existing share (that is, a stock dividend is treated just like a split). If the shares do not continue to be traded, the shareholder sells at the last reported transaction price. The proceeds of the sale are considered the terminal payout. If a firm's shares are still traded in 1991, our hypothetical shareholder sells at the end of that year. Our hypothetical shareholder pays no taxes on any transactions.

\section{Specification and Instruments}

Our interest in this paper is in the way that market discounts are associated with observable characteristics of firms. For this purpose, we use the following model:

$$
z_{i, t}=\mu\left(x_{i, t} \gamma\right)+\mathrm{u}_{i, t}+\epsilon_{i, t} .
$$

Here $z_{i, t}$ is the value shortfall calculated by using the standard principles of finance theory, $\mu\left(x_{i, t} \gamma\right)$ is an extra discount obtained by applying the vector of parameters $\gamma$ to $x_{i, t}$, a vector of characteristics of firm $i$ in year $t$. Each element of $\gamma$ tells how the corresponding characteristic influences the market discount rate applied to the dividends of the firm. The disturbance $u_{i, t}$ is noise in the firm's market value not associated with the observed characteristics of the firm, and the disturbance $\epsilon_{i, t}$ is the error in the market's expectations of future dividends.

We choose our right-hand variables, $x_{i, t}$, so that they are uncorrelated with the disturbance, $\epsilon_{i, t}$. That is, we use characteristics that are known to the market at the time that the stock price is determined. Because expectations are formed on the basis of our variables (along with many other variables that we do not include), the expectation error will not be correlated with our variables if expectations are rational.

Within the wide group of variables known at time $t$, we choose a particular group to suit the purposes of our research. As we explained earlier, our purposes are quite different from previous work in finance that has demonstrated the existence of valuation anomalies. Finance research has shown-without exception, as far as we know-that variables constructed from the current stock price are the best way to show that there are variables known at time $t$ that are correlated with subsequent increases in value. In place of our equation 2 , finance economists 
have broken down the observed relation between the stock price and subsequent dividends into two components:

$$
z_{i, t}=\eta_{i, t}+\epsilon_{i, t} .
$$

Their research has concentrated on showing that overall noise, $\eta_{i, t}$, is present. Our procedure is, in effect, to regress overall noise on certain characteristics of the firm, chosen to answer the questions that motivate our research. We thus break down overall noise into two components, the part associated with our selected firm characteristics, $\mu\left(x_{i, t}, \gamma\right)$, and a residual, $u_{i, t}$, which is uncorrelated with the characteristics.

It would be contrary to our purposes to include any right-hand variable that is inherently correlated with the valuation error, $u_{i, t}$. As a practical matter, this means that our right-hand variables should not depend on the current stock price. It would be impossible for the stock price not to be correlated with the valuation error. By analogy, in a standard regression setting, one can never include as a right-hand variable a variable that is an important part of the left-hand variable. To put the point differently, we gain nothing by identifying a firm as having the characteristic "undervalued in the stock market" and then showing that undervalued firms suffer higher discounts of their future expected dividends. The inclusion of a variable based on the stock price would bias the coefficients of the characteristics we are interested in, because the stock price is correlated with those characteristics.

In this respect, our research is fundamentally different from work in finance that seeks to show that there are undervalued firms and that investment in those firms yields arbitrage profits. We take that point as given and ask to what extent undervaluation can be associated with firm characteristics. Our results do not identify the most promising arbitrage strategies. To find them, we would include all possible variables, both firm characteristics and pure predictors based on measures of undervaluation derived from the current stock price.

Although we generally interpret our results as showing how the market discounts firms with different characteristics, with the implicit hypothesis that causation runs from characteristics to discounting, we cannot rule out causation in the opposite direction. This issue arises most acutely for investment. If firms that enjoy purely accidental higher valuation and lower discounts respond by investing more, investment will be associated with lower discounts and higher valuations. For this reason, 
we are cautious in placing an aggressive causal interpretation on our findings.

\section{Stock Price Levels or One-year Returns?}

There is a dispute within finance theory between proponents of studying the levels of security prices (the tradition started by Shiller and LeRoy-Porter) and the proponents of studying the returns over fairly brief holding periods (sometimes called the Euler equation approach). John Cochrane has argued that there is no substantive difference between the two approaches. ${ }^{11}$ In our own work, the issue arises in terms of the serial correlation of the combined disturbance in our valuation equation, $u_{i, t}+\epsilon_{i, t}$. If the serial correlation coefficient is close to 1.0, once we correct for serial correlation with an autoregressive transformation, we will be dealing with a variable similar to one-year returns. In that case, our finding of higher discounts associated, say, with higher book earnings could be reformulated as persistently higher future oneyear returns for a firm with above-average book earnings in a particular year.

On the other hand, if the serial correlation is substantially less than 1.0 , our approach is different from, and markedly superior to, the approach based on one-year returns. A lower serial correlation will arise if the noise component of the disturbance is a large part of the story, and the serial correlation of the noise is much less than 1.0. The serial correlation of the expectation error is inherently close to 1.0. The superiority of our approach is just the standard econometric point that an estimator is more efficient if it takes proper account of the covariances of the disturbances. The effect of an autoregressive transformation with a coefficient of close to 1.0 is to give very little weight to low-frequency movements of the left- and right-hand variables. Our interest is precisely in a low-frequency phenomenon, namely chronic excess discounting of dividends in general and those of certain types of firms in particular. We get much more precise estimates of our coefficients if our autoregressive correction uses a parameter well below 1.0 than if it uses a parameter of 0.9 or above.

11. Cochrane (1991). 
Our example of the S\&P 500 illustrates this point dramatically. Our standard error for the excess discount is 32 basis points. The serial correlation parameter used in this estimate is 0.40 . In contrast, the standard error of the estimate of the mean of the excess return is 220 basis points; the implicit autoregressive parameter is around 0.94 . If we repeat our method with an autoregressive parameter of 0.94 , we get a standard error of about 190 basis points.

In our panel data, however, we find serial correlations of the excess valuations of close to 1.0, so we do not achieve the sharp results that are available for aggregate data. Noise at the firm level appears to be much more persistent than at the aggregate level.

\section{Relation to the Work of Brainard, Shoven, and Weiss}

Our work has some of the same objectives as the major project of William C. Brainard, John C. Shoven, and Laurence Weiss (BSW). ${ }^{12}$ Their project covered much more ground than ours. We consider the valuations of particular securities: the common stocks of firms. BSW considered the valuation of entire firms. They viewed the holders of the equity and debt of a firm as having access to the entire cash flow of the firm, while we look only at the value that the market places on the dividends that managers choose to pay to their shareholders.

BSW's major theme was the collapse of the market value of firms in relation to their projected cash flows from 1968 to the last year included in the paper, 1977. At the time, the perversely low level of the stock market loomed large in any analysis of corporate valuation. From today's perspective, the depressed stock market of the 1970s seems less significant. Figure 3 shows that the market did undervalue corporations from 1974 through 1979, but that this undervaluation was not severe by historical standards. The fairly close tracking of actual stock prices and discounted future dividends in the 1980 s makes the overall record seem much closer to the predictions of valuation theory than the reader of the 1980 paper would think. ${ }^{13}$

12. Brainard, Shoven, and Weiss (1980).

13. Robert Hall was one of the discussants of the 1980 paper. He wrote, "Only the surge in stock prices since the authors began work on this paper threatens to undermine its conclusion. . . Whatever the explanation of low market values, the lesson seems to be to buy stocks." R. Hall (1980b, pp. 506, 508). This is the only published personal financial advice he has ever offered and he plans to quit while he is ahead. 
BSW's measure of undervaluation in the mid-1970s was much greater than the one shown in figure 3. Part of the reason appears to be that dividend payouts were low at that time relative to earnings. BSW projected levels of earnings that did not materialize as later dividends, it would appear.

BSW considered risk within essentially the same framework as we have adopted in this paper. In a subsequent paper, William C. Brainard, Matthew D. Shapiro, and John C. Shoven pursue risk measurement extensively. ${ }^{14}$ They use a conventional measure of the risk of a portfolio based on the covariance of its return with the market return, and also a novel measure of "fundamental" risk based on the covariance of a firm's earnings with aggregate earnings. They find that the price of fundamental risk is surprisingly low, although there is no question that fundamental risk helps explain differences in expected returns among firms. We hope to use similar risk measures in future research.

\section{Risk and Value}

Finance theory is unsettled about the measurement of risk. In principle, a household's marginal utility of consumption provides a logical way to measure the extra discount that should be applied to a risky asset. What matters is the nondiversifiable risk of an asset. Once the household has made the optimal selection of a diversified portfolio, the risk discount for one asset should be related to the covariance of the return of that asset with marginal utility. As the covariance becomes more negative, there is a greater tendency for the asset to pay less when times are bad, as measured by high marginal utility. The consumption capital asset pricing model (CCAPM) provides, in theory, a complete answer to the question of the pricing of risk.

The failure of the CCAPM is notorious in finance theory. Sanford Grossman and Robert Shiller showed that returns on stocks and bonds have almost exactly the same covariance with marginal utility, when the latter is taken from a constant-elasticity (constant relative risk aversion) utility function. ${ }^{15}$ Thus both stocks and bonds should have the same risk discount, and further, it should be a tiny fraction of 1 percent. In fact,

14. Brainard, Shapiro, and Shoven (1991).

15. Grossman and Shiller (1981). 
stocks consistently provide returns of about 5 percent per year in excess of bonds. The CCAPM gives no insight into the premium paid by stocks, or, to put it differently, it cannot explain why the market prices stocks as if they were much riskier than bonds. The same puzzle was explored further by Rajnish Mehra and Edward C. Prescott in their well-known paper. ${ }^{16}$

Lars Peter Hansen and Ravi Jagannathan extended this line of work by asking about the stochastic properties of an unobserved variable that might be playing the role that theory assigns to marginal utility. ${ }^{17}$ They found that the volatility of such a variable must be surprisingly high in order to rationalize the equity premium. Cochrane and Hansen provide a detailed summary of the current state of this line of thought. ${ }^{18}$

We verified that the covariance of the dividends of our sample of firms with marginal utility calculated from aggregate consumption was almost exactly zero. We concluded that the CCAPM provided no help in understanding the substantial extra discount that the market applies to the dividends of our firms relative to the future returns from Treasury bonds.

An older view in finance theory takes a more modest and empirical approach to the pricing of risk. The traditional CAPM (TCAPM) takes no stand on why a broad, diversified portfolio like the S\&P 500 is valued at a discount relative to riskless securities. Rather, it simply takes that extra discount as data. The TCAPM prices individual risky securities by comparing their risk to the risk of the market portfolio. This risk is measured by regressing the individual security's returns on the market return to find the beta. The risk premium for the security is just the beta times the market premium over the risk-free rate.

In principle, the concept of return that is relevant in our framework of long holding periods is the dividend; the beta should be measured by regressing one stock's dividend growth on the dividend growth of the market portfolio. ${ }^{19}$ We experimented with regressions of this type, but found, as with the CCAPM, that the covariances are essentially zero. The reason that the TCAPM yields sensible results as normally applied

16. Mehra and Prescott (1985). Also see Mankiw and Shapiro (1986).

17. Hansen and Jagannathan (1991).

18. Cochrane and Hansen (1992).

19. Brainard, Shapiro, and Shoven (1991) make the same observation with respect to earnings; they measure the "fundamental" beta by regressing a firm's earnings on aggregate earnings. 
is that beta is measured from returns for very brief holding periods, such as one day. The high covariance of these returns with the market comes not from changes in dividends, but from changes in the market capitalization ratios for dividends that are common across stocks. Our procedure was to use an excess discount of 5.28 percent to discount all of the stocks in our sample.

\section{The Critique of American Capitalism}

Many economists, and even more managers and noneconomist commentators, believe that there are important departures from the financetheory model of the stock market. Two important recent statements of this view by economists are by Michael Porter and by Kenneth Froot, Andre Perold, and Jeremy Stein. ${ }^{20}$ James Poterba and Lawrence Summers document the extreme prevalence of the view among managers. ${ }^{21}$ In our framework, the critique holds that the market systematically discounts the expected future performance of some types of firms at excessive rates. Even though this fact is known in the market, arbitrageurs do not exploit the fact; they are too busy chasing arbitrage profits available from short-term trading strategies. Managers respond to the perverse market valuation of their activities by pursuing projects that are highly valued and avoiding those that are discounted excessively. The critique has an important international comparative element. In Japan and Germany, there are significant permanent investors in firms who are informed about the prospective performance of firms and are capable of and interested in arbitrage to take advantage of any valuation failures that might appear in the market. Consequently, Japanese and German firms can invest in invisible activities, with negative effects on current earnings but high contribution to eventual performance, from which the U.S. firm is barred. In particular, the Japanese firm can sacrifice current earnings by penetrating huge markets with low prices, with high deferred value once the markets are fully developed. The comparison of the Japanese and U.S. auto industries invites this interpretation.

As Froot, Perold, and Stein emphasize, high turnover among share-

20. Porter (1992) and Froot, Perold, and Stein (1993).

21. Poterba and Summers (1993). 
holders is not by itself good evidence that the United States lacks investors willing to take long-term arbitrage positions. We know that the labor market has high average turnover rates at the same time that most work is done in the course of employment relationships that will last a large fraction of a lifetime. ${ }^{22}$ Similarly, in the stock market, high average turnover is completely consistent with the existence of a significant fraction of committed shareholders who will never sell. Froot, Perold, and Stein cite evidence that this is precisely the case in Germany and Japan, where turnover rates in share ownership are actually higher than in the United States. In both countries, banks hold long-term equity positions in corporations. By contrast, modern American capitalism has few core shareholders. Most shares are held by institutions that are legally required to be extremely diversified and are barred from holding significant shares of the ownership of any one corporation. Moreover, these institutions trade all their holdings actively and do not have traditions of long holding period arbitrage.

The United States has free entry in financial intermediation. Although two important types of intermediaries-banks and mutual funds-face major legal obstacles to long-term arbitrage in the stock market, other intermediaries can operate without limitations. Recently, three funds have entered the market with the precise intent of long-term arbitrage based on "relationship investing." These are Allied Partners, created by Dillon, Read \& Company, Corporate Partners, created by Lazard Freres, and Lens, created by Robert A.G. Monks. These funds make sizable investments and typically take one or more board seats. In view of the general responsiveness of the U.S. economy to arbitrage opportunities and the response that has actually occurred, it would be unreasonable to project the continuation of large arbitrage opportunities in the future. Our findings support the idea that arbitrage has improved over time; the U.S. stock market put a higher value on future dividends in the 1980s than in earlier decades.

Porter summarizes the short time-horizon critique of American capitalism in these words:

Because of their fragmented stakes in numerous companies, short expected holding periods, and the lack of access to "inside" information through disclosure or board membership, institutional investors tend to heavily base buy/sell choices on relatively limited information that is oriented toward predicting near-

22. R. Hall (1980a). 
term price movements. They are driven by the system to focus on measurable company attributes, such as current earnings or patent approvals, as proxies of a company's value. The value proxies employed vary among different classes of companies and can lead to underinvestment in some industries or forms of investment, while allowing overinvestment in others. ${ }^{23}$

Porter later explains that "the dominant value proxy employed by investors and analysts is current earnings, which has a demonstrably strong effect on share prices." ${ }^{24}$ As evidence in support of this view, he observes that earnings announcements tend to cause changes in share value. But this evidence is inconclusive because even the strictest finance theory view with no arbitrage opportunities would hold that new information about earnings should cause changes in share prices. Our framework provides a way to look for excess sensitivity of stock prices to earnings. We look for an effect of earnings on stock prices beyond what is merited by actual subsequent performance. If the critique is correct and investors are using current earnings as an inappropriate proxy for subsequent performance, then we should find that firms with higher earnings enjoy lower discount rates for their future performance. In fact, we find the opposite: high-earnings firms suffer higher discounting of their subsequent performance.

Porter also identifies biases in the composition of investment:

The American system favors those forms of investment for which returns are most readily measurable, due to the importance of financial returns and the limited information available to investors and managers. For most companies, investments in plant and equipment with easy-to-measure cash flows are more confidently valued and justified than investments in $R \& D$, training, or other forms where the returns are more difficult to quantify. Intangible assets such as reputation, a technical base, or information systems are far more difficult for value proxy and event forecast valuation methods to handle, even though they have a major impact on competitiveness. Internally intangible assets are often not treated as investments, and their cash flows are hard to assess. ${ }^{25}$

For exactly the reasons Porter mentions, we lack data on many forms of intangible investment. Future research may be able to develop measures of training, reputation, market development, information systems, customer and supplier relationships, and other intangibles not reported in corporations' financial statements. We are able to study the relationship

23. Porter (1992, p. 8).

24. Porter (1992, pp. 43-44).

25. Porter (1992, pp. 63-64). 
between hardware investments and the discounting of subsequent performance, with results that give considerable support to the critique. Firms with higher plant and equipment investment enjoy lower discounts and higher share prices. We also look at two intangibles, R\&D and advertising. Here our results are mixed. There is weak evidence that R\&D-intensive firms enjoy lower discounts of subsequent performance, contrary to the critique. On the other hand, the critique finds support in our finding that advertising-intensive firms suffer higher discounting of future performance, although Porter and others have hardly stressed that one of the failures of American capitalism is to advertise too little.

One of the themes of the short time horizon critique is that the situation has worsened over time. Porter notes that institutional shareholders rose from 8 percent of the market in 1950 to 55-60 percent in 1990 and that the average holding period for stocks fell from seven years in 1960 to two years in the 1990s ${ }^{26}$ Burton Malkiel provides evidence that the market valued expected dividend growth much less in the 1980s than in the 1960s, which he interprets as evidence that time horizons of investors in the stock market shortened ${ }^{27}$ (We will discuss his method later in this paper.) Our approach to the issue of changes over time is simply to repeat our analysis for each of the three decades spanned by our data. We find evidence of lengthening time horizons or lessening excessive discounting of future performance.

An important element of the critique of American capitalism is that managers focus attention on current stock prices when the attention would better be placed on long-term performance. Obviously, in an economy where the market gave the best possible valuation of expected future performance, the focus on the current stock price serves efficiency. But defective stock-market valuations based on value proxies will make managers emphasize activities that affect the proxies favorably, contrary to the dictates of efficiency. Because we use the benchmark of actual subsequent performance, which will include all the adverse effects of distorted managerial incentives, we cannot comment on this aspect of the critique. Bronwyn Hall looks at one important aspect of this issue-R\&D investment-in a 1993 paper, ${ }^{28}$ and Warren Farb considers hardware investment. ${ }^{29}$

26. Porter (1992, p. 59).

27. Malkiel (1993).

28. B. Hall (1993b).

29. Farb (1993). 


\section{Data}

We use a sample of the great majority of publicly traded firms in manufacturing assembled by Bronwyn Hall in connection with earlier work. ${ }^{30}$ Data on year-end stock prices, on terminal prices due to takeovers, and on dividends and other distributions to shareholders are from the Center for Research on Securities Prices (CRSP), University of Chicago. Data on balance sheets and operating statements are from Compustat. Data on "bullet rates" (the implied prices of pure discount instruments) from the U.S. Treasury securities market are taken from the work of Thomas S. Coleman, Lawrence Fisher, and Roger G. Ibbotson. ${ }^{31}$ We define the variables as follows:

The stock price is the closing share price on the last business day of the year, adjusted for splits.

The dividend comprises dividends or other cash distribution to shareholders, including cash received from takeover or liquidation, or the terminal stock price at the end of 1991. Except for the terminal stock price, we assume all dividends are received in the middle of the year.

The discount is the bullet discount rate from Coleman, Fisher, and Ibbotson, ${ }^{32}$ multiplied by 0.9472 raised to the power of the number of years into the future.

Assets are the book value of plant, equipment, inventories, and investments in unconsolidated subsidiaries, taken at the end of the year and adjusted for effects of price changes.

$R \& D$ is the spending on research and development during the year.

Advertising is the spending on advertising during the year.

Investment is spending on plant and equipment during the year.

Debt is measured as the book value of outstanding long-term debt, taken at the end of the year.

30. Bound and others (1984), B. Hall and others (1988), and B. Hall (1990). The data set is the multigenerational lineal descendent of the heroic efforts of Arthur Slepian for Brainard, Shoven, and Weiss (1980). The results presented in this version of the paper are for about half the total sample: those based on companies whose fiscal years are calendar years.

31. Coleman, Fisher, and Ibbotson (1989).

32. Coleman, Fisher, and Ibbotson (1989). 
Earnings are book earnings per share, after deducting interest and taxes, not including extraordinary special items, for the preceding year. (For example, for the observation using the stock price as of December 31, 1986, the earnings are for the calendar year 1985.)

Value shortfall is as defined in equation 1: the difference between actual present discounted value of dividends and share price, all divided by the share price.

We specify our regression as follows:

The dependent variable is the current value shortfall less the serial correlation coefficient for this year, multiplied by next year's value shortfall.

Independent variables consist of the following ratios, plus a dummy for each year, serially transformed: R\&D-assets, advertising-assets, investment-assets, debt-assets, retained earningsassets, and dividends-assets.

The instruments used as predictors of the independent variables are specified as follows. We define the discounted dividend predictor as the current dividend yield multiplied by the sum of the future discounts from this year through 1991 (see appendix B for a more complete discussion); the instruments are a full set of annual dummy variables, the annual dummies multiplied by the discounted dividend predictor, the six firm characteristics, the six characteristics multiplied by the discounted dividend predictor, and the six characteristics multiplied by the discounted dividend predictor with dividends lagged one year.

Table 1 presents descriptive statistics for the data: mean, median, and interquartile range (location of twenty-fifth and seventy-fifth percentiles). The information in parentheses alongside each variable name is the trimming criterion we used for excluding observations based on the values of the variable.

Note that both $R \& D$ and advertising are small in relation to assets. The low values of R\&D and especially advertising in the period 196470 result from the fact that many firms omitted these items from their operating statements during the 1960s. (Financial Accounting Standards Board reporting requirements for these items were instituted in the early 1970s.) Because we include dummies for missing data in our valuation equation, omitted data do not bias the results, but we do not consider 
Table 1. Statistics on Variables Used in Regressions

Percent

\begin{tabular}{|c|c|c|c|c|c|}
\hline Variable (cutoff) ${ }^{\mathrm{a}}$ & $1964-90$ & $1964-70$ & $1971-80$ & $1981-90$ & $\mathbf{R}^{2}$ \\
\hline \multicolumn{6}{|l|}{ R\&D-assets ( $<50$ percent $)$} \\
\hline Mean & 2.70 & 1.34 & 2.24 & 3.69 & 0.48 \\
\hline Median & 0.94 & 0.00 & 1.04 & 1.56 & $0.19^{b}$ \\
\hline Interquartile range & $0,3.64$ & $0,1.56$ & $0,3.21$ & $0,4.91$ & \\
\hline \multicolumn{6}{|l|}{ Advertising-assets $(<50$ percent $)$} \\
\hline Mean & 2.16 & 0.16 & 2.26 & 2.76 & 0.48 \\
\hline Median & 0.00 & 0.00 & 0.00 & 0.00 & $0.27^{b}$ \\
\hline Interquartile range & $0,1.94$ & 0,0 & $0,2.00$ & $0,2.73$ & \\
\hline \multicolumn{6}{|l|}{ Investment-assets ( $<50$ percent) } \\
\hline Mean & 9.06 & 9.73 & 8.39 & 9.58 & 0.41 \\
\hline Median & 7.72 & 8.77 & 7.19 & 7.93 & $0.20^{\mathrm{b}}$ \\
\hline Interquartile range & $5.06,11.5$ & $6.23,12.3$ & $4.77,10.6$ & $5.06,12.2$ & \\
\hline \multicolumn{6}{|l|}{ Debt-assets ( $<200$ percent $)$} \\
\hline Mean & 25.96 & 26.77 & 23.86 & 28.03 & 0.36 \\
\hline Median & 22.98 & 24.22 & 22.27 & 23.16 & $0.19^{b}$ \\
\hline Interquartile range & $12.2,34.7$ & $16.2,34.0$ & $11.6,32.6$ & $10.9,38.3$ & \\
\hline \multicolumn{6}{|c|}{ Lagged earnings-assets ( $<50$ percent) } \\
\hline Mean & 16.66 & 26.13 & 17.41 & 12.50 & 0.57 \\
\hline Median & 9.90 & 16.18 & 10.13 & 8.52 & $0.29^{b}$ \\
\hline Interquartile range & $4.4,21.8$ & $6.8,34.9$ & $4.86,22.7$ & $3.26,17.6$ & \\
\hline \multicolumn{6}{|l|}{ Dividends-assets ( $<20$ percent) } \\
\hline Mean & 2.58 & 3.39 & 2.43 & 2.47 & 0.60 \\
\hline Median & 2.04 & 3.01 & 1.93 & 1.79 & $0.35^{\mathrm{b}}$ \\
\hline Interquartile range & $0.72,3.46$ & $1.82,4.33$ & $0.90,3.11$ & $0,3.42$ & \\
\hline \multicolumn{6}{|l|}{ Value shortfall $(<1000$ percent $)$} \\
\hline Mean & -5.29 & -23.82 & 7.22 & -12.90 & \\
\hline Median & -17.83 & -36.66 & -7.23 & -20.68 & \\
\hline Interquartile range & $-50.8,25.1$ & $-59.7,-0.2$ & $-44.6,41.7$ & $-52.5,16.7$ & \\
\hline \multicolumn{6}{|l|}{ Addendum } \\
\hline Percent on NYSE or AMEX & $\cdots$ & 100 & 72 & 58 & \\
\hline Number of observations & 11,032 & 1,561 & 5,022 & 4,449 & \\
\hline
\end{tabular}

Source: Authors' calculations based on Compustat and CRSP data on U.S. manufacturing firms. For definitions of variables, see the text.

a. The values at which observations were trimmed are shown alongside the variable names.

b. The $\mathrm{R}^{2}$ is for the regression of quasi-first-differences.

our estimates of the effects of the two variables on valuation in the $1960 \mathrm{~s}$ to be reliable.

The next-to-last line in table 1 shows another important feature of the data. All our data for the 1960s come from firms listed on the two major exchanges-the New York and the American (NYSE/AMEX). The sample includes a fair number of over-the-counter (OTC) firms in the 1970s, and even more in the 1980s. The composition of the sample shifts 
toward smaller firms over time. This feature of the sample, which seems to have little effect on our results, is dictated by Compustat's changing coverage of firms.

\section{Results}

Table 2 shows our basic results for the entire period, 1964-90. Each coefficient shows the number of percentage points by which the annual discount rate applied to future dividends increases for a unit change in the corresponding firm variable. For example, the coefficient of -7.84 for the investment-assets ratio indicates that an increase in investment by the amount of assets (that is, an increase of 1.0 in the investmentassets ratio) lowers the discount rate by 7.84 percentage points. Obviously, differences of this magnitude are not found in the data. The second column of table 2 shows the effect on the discount in basis points for a one-standard-deviation increase in the corresponding variable. For example, a one-standard-deviation increase in the investment-assets ratio (an increase of 0.060 ) decreases the discount rate by 0.47 percentage points.

Our results show that $\mathrm{R} \& \mathrm{D}$-intensive firms enjoy lower discounts. A firm that is one standard deviation above average in its ratio of $R \& D$ spending to assets has a discount about half a percentage point lower than average. There is considerably more sampling variation in the estimate of this coefficient than in the one for hardware investment. Advertising-intensive firms face slightly higher discounts. Not only is the coefficient small in magnitude, but it is very small in relation to the statistical uncertainty as measured by the standard error.

On the other hand, firms with high levels of investment in plant and equipment enjoy substantially lower discounts and higher share values. The coefficient of -7.84 percentage points represents an important effect of investment on discounting: the discount rate is 47 basis points lower for a firm that is one standard deviation higher in the distribution of the investment-assets ratio. The coefficient is measured with considerable precision, as shown by its standard error of 1.78 percentage points.

The results show that debt has little effect on the firm's discount rate. A firm one standard deviation above average in this distribution has a 
Table 2. Coefficient Estimates for Firm Variables and Their Corresponding Effects on the Discount Rate ${ }^{a}$

\begin{tabular}{lcc}
\hline Independent variable & Coefficient & $\begin{array}{c}\text { Effect on discount } \\
\text { of one standard } \\
\text { deviation increase } \\
\text { (basis points) }\end{array}$ \\
\hline Constant & -2.02 & $\ldots$ \\
R\&D-assets & $(0.68)$ & -51 \\
Advertising-assets & -11.87 & 14 \\
Investment-assets & $(6.75)$ & -47 \\
Debt-assets & 2.49 & \\
Lagged earnings-assets & $(3.83)$ & \\
& -7.84 & 74 \\
Dividends-assets & $(1.78)$ & 1 \\
Summary statistic & 1.07 & \\
SER & $(1.02)$ & \\
$\mathrm{R}^{2}$ & 3.12 & \\
Durbin-Watson & $(0.44)$ & \\
Number of observations & 11,032 & \\
\hline
\end{tabular}

Source: Authors' calculations based on Compustat and CRSP data.

a. The dependent variable is the current value of the shortfall less the serial correlation coefficient for the current year, multiplied by next year's shortfall. Two dummy variables for R\&D expenditures equal to zero and advertising expenditures equal to zero have also been included in the regression. Standard errors are shown in parentheses.

discount rate 22 basis points higher. This finding goes in the direction predicted by finance theory: all else held constant, a more leveraged firm has higher nondiversifiable risk and a higher discount rate. But the coefficient is not large, and is only slightly larger than its standard error.

Firms with higher book earnings in relation to assets have higher discounts in the market. Far from favoring the current bottom line, the market seems to place a lower value on a firm with unusually high earnings. A firm one standard deviation higher in the distribution of assets faces a discount about three-quarters of a percentage point higher. The finding is statistically unambiguous and is the most robust of all of our findings. Our conclusion that an investor can beat the market by selecting firms with high earnings relative to assets is an interesting complement to earlier findings that investing in firms with high earnings-price ratios is a 
good strategy. Our results show that the role of earnings is more than just to normalize the stock price. It is smart to buy stocks with high earnings-price ratios both because stocks with high earnings are attractive and because stocks with low prices are attractive. We have confirmed this point by including the assets-price ratio in a variant of the equation estimated in table 2, but for reasons explained earlier, we do not pursue specifications that include the stock price.

We find only a tiny effect of dividend policy on discounting. Because there is relatively little variation in dividends compared to the other variables, the standard error of the coefficient relating dividend policy to discounting is relatively high.

Table 3 breaks the results down by decade. Recall that the sample for the 1960s is made up entirely of firms listed on the New York or American stock exchanges. The over-the-counter market is not represented in the sample until the 1970s and becomes a much larger part of the sample in the 1980s. We estimated the valuation equation separately for NYSE/ AMEX firms and OTC firms, and found remarkably little difference. A second prefatory comment is that the results for the 1980s are for much shorter holding periods than for the earlier decades, both because all firms have terminal prices in 1991 if not before, and because takeovers were much more common in the 1980s.

Most of the results are reasonably consistent across the three decades, after consideration of sampling variation. The R\&D coefficientshowing lower discounting for firms investing in this form of intangible capital-is considerably larger in the 1970s and 1980s, although for the 1980s this may be the result of sampling variation alone. The effect of advertising on discounting is very large in the 1980 s, a puzzle we plan to investigate more thoroughly in future work. The effect of debt on a firm's discount rate is small in all three decades. The adverse effect of book earnings on discounting is also confirmed in all three decades and becomes conspicuously stronger in the $1980 \mathrm{~s}$.

The addendum to table 3 shows the fitted discount rate for the median and mean firms in the three decades. The median firm has the characteristics of the median values of the six firm variables calculated over the entire period (the values of the variables used to calculate the discounts in table 3 are the same for the three decades; only the coefficients change). The mean firm has the mean values of the six characteristics. By both measures, the discounts fell dramatically in the 1980s. The discount rate we find to apply in the stock market for the median or mean 
Table 3. Regression Results by Decade ${ }^{\mathrm{a}}$

\begin{tabular}{lccc}
\hline Independent variable & $1964-70$ & $1971-80$ & $1981-90$ \\
\hline Constant & -0.57 & 1.11 & -3.57 \\
& $(1.19)$ & $(0.65)$ & $(1.49)$ \\
R\&D-assets & -3.70 & -15.78 & -20.50 \\
& $(12.03)$ & $(7.70)$ & $(13.57)$ \\
Advertising-assets & -37.88 & 0.38 & 11.40 \\
& $(10.91)$ & $(4.63)$ & $(6.48)$ \\
Investment-assets & -2.45 & -8.74 & -11.72 \\
& $(3.80)$ & $(2.59)$ & $(4.33)$ \\
Debt-assets & 2.59 & -2.13 & -1.11 \\
& $(1.56)$ & $(1.27)$ & $(2.16)$ \\
Lagged earnings-assets & 2.57 & 2.27 & 6.30 \\
& $(0.78)$ & $(0.62)$ & $(1.35)$ \\
Dividends-assets & -3.45 & 18.50 & 42.79 \\
& $(9.69)$ & $(10.79)$ & $(15.60)$ \\
Summary statistic & & & \\
SER & 39.53 & 37.05 & 31.41 \\
$\mathrm{R}^{2}$ & 0.05 & 0.14 & 0.01 \\
Durbin-Watson & 1.46 & 1.37 & 1.51 \\
Number of observations & 1,561 & 5,022 & 4,449 \\
Addendum & & & \\
Discount rate of the median firm & -2.94 & 0.07 & -4.80 \\
& $(1.56)$ & $(0.88)$ & $(1.97)$ \\
Discount rate of the mean firm & -2.56 & -0.19 & -3.93 \\
& $(1.50)$ & $(0.91)$ & $(1.98)$ \\
\hline
\end{tabular}

Source: See table 2 .

a. The dependent variable is the current value of the shortfall less the serial correlation coefficient for the current year, multiplied by next year's shortfall. Two dummy variables for R\&D expenditures equal to zero and advertising expenditures equal to zero have also been included in the regression. Standard errors are shown in parentheses.

firm is the risk-free discount plus 5.28 percent for the equity premium less the numbers given in table 3. By the 1980s, the median firm had gained back almost all of the equity premium and the mean firm had made about a percentage point less progress.

\section{Relation of Our Findings to Burton Malkiel's}

Our results offer much less support to the hypothesis of stock-market myopia than those of Burton Malkiel. ${ }^{33}$ Whereas we find less myopia in

33. Malkiel (1993). 
the 1980s than earlier, Malkiel interprets his evidence as showing much more myopia recently. Malkiel's basic finding is that the cross-section regression of firms' price-earnings ratios on earnings growth forecasts of Wall Street analysts yields a much smaller coefficient for data from the 1980s than for data from the 1960s. An additional finding, which he considers highly supportive of worsening myopia, is that much of the decline has occurred in the coefficient of five-year-ahead earnings growth expectations, rather than in the coefficient of one-year-ahead expectations.

We believe that the use of analysts' earnings growth forecasts would be a useful addition to our own work. At a minimum, they would provide extra predictive power in our first-stage regressions. However, we do not believe that Malkiel's use of the growth forecasts has much to say about myopia. The problem arises in his use of the price-earnings $(\mathrm{P} / \mathrm{E})$ ratio as the dependent variable in his regressions. Much of the cross-sectional variation in $\mathrm{P} / \mathrm{E}$ ratios in a given year comes from transitory fluctuations in earnings. A company can have a lofty $\mathrm{P} / \mathrm{E}$ either because it has excellent long-run growth prospects or because earnings are temporarily depressed. Studying $\mathrm{P} / \mathrm{E}$ ratios in a cross section would be analogous to studying the average propensity to consume in a cross-section study of consumption. Families with temporary declines in income can have average propensities to consume of unlimited positive values; so can the $\mathrm{P} / \mathrm{E}$ ratios of firms. And a family or a firm that had a loss in a particular year would be a still bigger problem.

The regression coefficient of the $\mathrm{P} / \mathrm{E}$ ratio on earnings growth, as calculated in cross sections by Malkiel, does not have any tight connection to finance theory. Rather, it depends on the details of the stochastic process governing earnings. The coefficient is almost infinitely sensitive to the likelihood of near-zero earnings. It is equally sensitive to the treatment of firms with negative earnings. Changes in the mean and dispersion of earnings over time can have large effects on the cross-sectional regression coefficient. In the consumption literature, the analogous point is Milton Friedman's observation that the cross-sectional consumption function is different for farmers than for wage-earners because farmers have larger transitory components of earnings. ${ }^{34} \mathrm{Had}$ Friedman and others studying consumption in cross sections chosen to state the consumption function in terms of the ratio of consumption to income (as

34. Friedman (1957). 
Malkiel did for the stock market), the differences between farmers and wage-earners would have been much larger.

The book earnings of a corporation are the creation of accounting rules, which changed a great deal between the 1960s and the 1980s. Earnings are the shareholders' residual after paying interest to debtholders, so the probability distribution of earnings was heavily affected by the increased leveraging of the 1980s. Although we do not have the data to explain why Malkiel found such a larger reduction in his regression coefficient from the 1960s to the 1980s, nor to explain why the coefficient is so stable from year to year within each decade, we do not believe that regressions with the $\mathrm{P} / \mathrm{E}$ ratio as the left-hand variable are a good way to study the issue of changing myopia.

The alternative way to use Malkiel's data would be to start from his observation that a firm's stock price, $p_{t}^{*}$, should be related to its current dividends, $d_{t}$,

$$
p_{t}^{*}=\frac{d_{t}}{r_{t}-g_{t}},
$$

under the assumption that the current term structure is flat with interest rates for all maturities at $r_{t}$ and that dividends will grow at the constant rate $g_{t}$ for the indefinite future. If the actual share price, $p_{t}$, is consistently lower than $p_{t}^{*}$, it means that the market is shortsighted. And if the shortfall is greater in the 1980s than in the 1960s, it shows growing myopia. Our results suggest rather strongly that the first hypothesis would be supported, but not the second.

\section{The Critique of American Capitalism in Light of Our Results}

As we noted in our opening section, our finding that the equity premium-which defies explanation by standard finance theory-was about 2.5 percent in the $1960 \mathrm{~s}, 5$ percent in the $1970 \mathrm{~s}$, and 1 percent in the 1980s supports the hypothesis that the stock market is systematically shortsighted. It values payoffs in the more distant future at a low level compared to similar payoffs from government bonds. This finding supports the most basic element of the critique.

The critique holds that standard hardware investment-plant and equipment-should enjoy higher valuation on its future payoffs than intangible and invisible investments in market development and other 
nonhardware areas. Our results also support this hypothesis strongly. Firms with high levels of plant and equipment investment have higher values in the market, given their actual subsequent performance. The remarkably high positive coefficient on one measurable intangible-advertising-also supports the critique, but only in the 1980s.

One of the central propositions of the critique is that the U.S. stock market forces managers to aim for maximum reported bottom-line earnings, to the detriment of investments that hurt the bottom line in the short run but provide strong performance in the longer run. Our results reject this proposition decisively. To the contrary, one of the most promising long-run arbitrages suggested by our results is to buy firms that have unusually high current earnings. They are differentially likely to yield high ultimate value to their shareholders.

Our results for intangible $R \& D$ are also somewhat unfavorable to the critique. In the two decades when R\&D was generally reported in financial statements, it receives negative coefficients, showing that an investment in an $R \& D$-intensive firm has a higher than average long-term payoff to an investor than a normal firm. The statistical confidence in this finding is lower than for the others we have highlighted.

A final proposition central to the critique of American capitalism is that shortsightedness has worsened over time. Our results show just the opposite. Although the market valuation of the typical stock in the 1980s was still below the finance-theory benchmark, the shortfall was smaller. The U.S. stock market seems to be moving toward erasing its puzzling tendency toward excessive discounting. With steady rises in stock market values since the mid-1980s (even counting the collapse of the market in 1987), the problem of overdiscounting and shortsightedness may have vanished from the market, on the average, in the 1990s.

APPENDIX A

\section{Derivation of the Valuation Equation}

Let:

$t=$ year of valuation, as of the end of the year;

$\tau=$ year of future payout; 


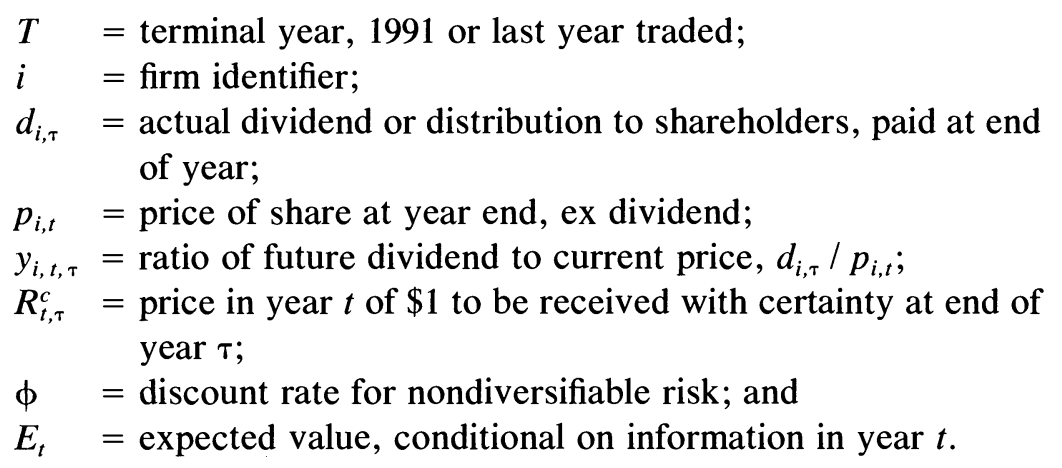

The valuation equation from finance theory is

$$
p_{t}=\sum_{\tau=t+1}^{T}(1-\phi)^{\tau-t} R_{t, \tau}^{c} E_{t} d_{\tau} .
$$

The present value of the future expected dividend yield of a stock should be equal to the price of the stock, with the present value calculated using the risk-free rate adjusted for extra discounting at rate $\phi$. The magnitude of the risk adjustment $\phi$ depends on the amount of economy-wide risk in the dividends of the stock. A stock has a higher discount if there is a general tendency for its dividends to fall in times of poorer general conditions.

We rewrite the valuation equation as

$$
p_{t}=\sum_{\tau=t+1}^{T} R_{t, \tau} E_{t} d_{\tau}
$$

where $R_{t, \tau}=(1-\phi)^{\tau-t} R_{t, \tau}^{c}$, the discount including the nondiversifiable risk factor. Our work is concerned with departures in the market from this valuation model. Our general approach is to look for excess discounts, $\delta_{i, t}$. Using the firm identifier, $i$, where appropriate, our generalized valuation model is

$$
p_{i, t}=\sum_{\tau=t+1}^{T} R_{t, \tau}\left(1-\delta_{i, t}\right)^{\tau-t} E_{t} d_{i, \tau}
$$

We will find it convenient to restate the valuation model in terms of the dividend yields as

$$
1=\sum_{\tau=t+1}^{T} R_{t, \tau}\left(1-\delta_{i, t}\right)^{\tau-t} E_{t} y_{i, t, \tau} .
$$


We define the unexpected element of payouts as

$$
\eta_{i, t, \tau}=y_{i, t, \tau}-E_{t} y_{i, t, \tau}
$$

and define the composite surprise,

$$
\epsilon_{i, t}=\sum_{\tau=t+1}^{T} R_{t, \tau}\left(1-\delta_{i, t}\right)^{\tau-t} \eta_{i, t, \tau} .
$$

Then we write the valuation model as

$$
1=\sum_{\tau=t+1}^{T} R_{t, \tau}\left(1-\delta_{i, t}\right)^{\tau-t} y_{i, t, \tau}-\epsilon_{i, t} .
$$

Our next step is to linearize the model in the excess discount, $\delta$, around the point $\delta=0$ :

$$
1=\sum_{\tau=t+1}^{T} R_{t, \tau} y_{i, t, \tau}-\delta_{i, t} \sum_{\tau=t+1}^{T}(\tau-t) R_{t, \tau} y_{i, t, \tau}-\epsilon_{i, t} .
$$

Excess discounting contributes a negative term to value, in which the discounted future dividends are weighted in proportion to their futurity.

Next we define

$$
z_{i, t}=\sum_{\tau=t+1}^{T} R_{t, \tau} y_{i, t, \tau}-1,
$$

the realized excess present value of the future dividend yields. Now we can write the valuation equation as:

$$
z_{i, t}=\delta_{i, t} \sum_{\tau=t+1}^{T}(\tau-t) R_{t, \tau} y_{i, t, \tau}+\epsilon_{i, t} .
$$

We define $k_{i, t}$ as the weighted discounted dividends,

$$
k_{i, t}=\sum_{\tau=t+1}^{T}(\tau-t) R_{t, \tau} y_{i, t, \tau} .
$$

We assume that the discount, $\delta_{i, t}$, can be written as a linear function of observed characteristics, $x_{i, t}$, with parameter vector $\gamma$, and a random noise component, $u_{i, t} / k_{i, t}$ :

$$
\delta_{i, t}=x_{i, t} \gamma+u_{i, t} / k_{i, t} .
$$

Then the valuation equation takes the simple form,

$$
z_{i, t}=k_{i, t} x_{i, t} \gamma+u_{i, t}+\epsilon_{i, t} .
$$


The literature on orthogonality tests of valuation equations is closely related to this equation. ${ }^{35}$ The literature can be interpreted as saying that, absent noise, the realization $z_{i, t}$ is orthogonal to any variable observed at time $t$. Durlauf and Hall noted that the fitted values from the regression of $z_{i, t}$ on variables known at time $t$ provided an estimate of the time series of valuation noise. The estimate is conservative in that the variance of the fitted value is a lower bound on the variance of the noise.

The difference between our approach and earlier work on orthogonality tests is easy to explain in this framework. The orthogonality approach makes inferences about the importance of the entire valuation noise, $k_{i, t} x_{i, t} \gamma+u_{i, t}$, whereas we are interested only in the first term and combine the second term with the expectation error. The DurlaufHall method could be used to make inferences about the part of our residual that comes from valuation noise not associated with our variables. The basic method would be to project our residuals onto variables constructed from the current stock price.

\section{APPENDIX B}

\section{Econometric Issues}

To estimate the model, we define the regressor vector

$$
X_{i, t}=k_{i, t} x_{i, t},
$$

so the valuation model becomes

$$
z_{i, t}=X_{i, t} \gamma+u_{i, t}+\epsilon_{i, t} .
$$

The distribution of the disturbance, $u_{i, t}+\epsilon_{i, t}$, is distinctly nonspherical. By dividing both sides of the valuation equation of the current share price, we eliminate the most obvious sources of heteroskedasticity across firms and across time. But there is likely to be high serial correlation of $u+\epsilon$, because it is a moving average of future expectation errors, and because valuation noise may also be persistent. There is a simple transformation that will make the disturbances of this equation roughly

35. See Startz (1982), Scott (1985), and Durlauf and R. Hall (1990). 
spherical and yet retain the orthogonality of $\epsilon_{i, t}$ to the instrumental variables. Suppose that the serial correlation of the disturbance, $u_{i, t}+\epsilon_{i, t}$, is approximately the same for all firms in year $t$; call the common value $\rho_{t}$. The standard forward autoregressive transformation of the data would make the covariance matrix diagonal, but it would destroy the orthogonality. Instead, we use a backward transformation:

$$
\tilde{z}_{i, t}=z_{i, t}-\rho_{t} z_{i, t+1} \text {. }
$$

We use the one-year Treasury bill discount as an estimate of $\rho_{t}$. We calculate transformed left- and right-hand variables using the backward autoregressive transformation.

\section{Instruments}

The estimating equation is

$$
z_{i, t}=X_{i, t} \gamma+u_{i, t}+\epsilon_{i, t} .
$$

Each element of $X_{i, t}$ is the product of a firm characteristic, $x_{i, t}$, and the weighted realization of discounted dividends, $k_{i, t}$. The instruments need to deal with the fact that $k_{i, t}$ declines in value as $t$ approaches the terminal date. We use the variable,

$$
h_{t}=\sum_{\tau=t+1}^{T}(\tau-t) R_{t, \tau},
$$

which is eligible as an instrument because it depends on information available at $t$. Then we use instruments of the form,

$$
\left(d_{i, t-j} / A_{i, t}\right) h_{t} x_{i, t} \text {, }
$$

or various lags, $j$, which should be the best predictors of $x_{i, t} k_{i, t}$. 


\section{Comments and Discussion}

John Heaton: Bronwyn Hall and Robert Hall consider whether the discounted value of a firm's future dividends is completely reflected in the firm's current stock price or whether dividends are discounted excessively because of investors' short horizons. First, the authors advocate forming an appropriate discount factor that reflects the aggregate or undiversifiable risk of a firm's dividend stream. As in Robert Shiller's 1981 work, the authors calculate an ex post rational value of the dividend stream by discounting actual future dividends using this discount factor. ${ }^{1}$ If the model of the discount factor is correct, then any deviation of the actual stock market price from this ex post rational price should reflect expectational errors and should be uncorrelated with current informational variables.

Instead of considering a general alternative to their chosen model of the discount factor, Hall and Hall examine a particular alternative in which extra discounting occurs because individual investors cannot, or do not, properly evaluate activities with very distant payoffs that are undertaken by firms. The authors consider whether differences in R\&D expenditures, advertising, investment expenditures, debt, earnings, and dividends across firms affect the discount factor applied to the firms' future dividend streams. In other words, Hall and Hall ask whether the difference between ex post rational stock prices and current stock prices is correlated with variables that could influence investors' effective horizons. To interpret the results, these variables are multiplied by a discount indicator, so that the level of discounting can be easily calculated. If investors have short horizons, then they should discount firms with high $R \& D$ investment more heavily than firms with low $R \& D$, once a

1. Shiller (1981). 
correction is made for the firm's riskiness (that is, once the correct asset pricing model is used).

Hall and Hall find several results that run counter to the notion that investors have short horizons. For example, firms with high levels of R\&D (relative to assets) face lower discount rates on future dividends. Further, firms with high current earnings relative to assets face higher discounting. This contrasts with the notion that firms in search of higher current stock prices could follow a strategy of increasing current earnings at the expense of future earnings. Further, Hall and Hall find that the excess discounting has been falling over time for the median firm in their sample. This provides some evidence against the notion that American capitalism suffers from the effects of myopic investors. However, the authors find that firms with larger investment in plant and equipment face lower discount rates-a finding that is consistent with the notion that investors like the short-term payoff from this type of investment.

Essentially, Hall and Hall are testing a particular model of asset pricing in which the systematic risk is assumed to be constant over time and its risk premium is given by the market risk premium. They are interested in a particular alternative in which there is excess discounting because of certain characteristics of firms investment patterns and earnings. Rather than examining the difference between the current stock price and the expost rational stock price, a more typical way to proceed would be to ask whether the cross-sectional pattern of one-period excess returns can be explained by a simple model such as the capital asset pricing model (CAPM). It is not clear why Hall and Hall did not proceed in this way. The paper asserts that it is more informative to look at discounted dividends instead, but these assertions are not substantiated. In fact, as the authors indicate, their correction for serial correlation of the error term results in a specification that is very close to examining a return specification. I suspect that similar results would obtain if Hall and Hall looked at one-period returns directly, so this is not likely to be an important issue.

An advantage of the return specification would be that the results could be compared with the large literature in finance theory that examines whether the cross-sectional distribution of asset returns can be explained by a simple risk factor such as beta. For example, there has been renewed focus on variables such as book-to-market value, firm size, price-earnings ratios, and dividend-price ratios in explaining differences in returns. 
Hall and Hall dismiss such results because they often use the stock price as part of the explanatory variables. However, the influence of financial variables such as book-to-market value and price-earnings ratios on excess returns could be the result of the short horizons of important classes of agents. For example, Josef Lakonishok, Andrei Shleifer, and Robert W. Vishny examine whether contrarian strategies can be used to help produce substantial returns with little risk. ${ }^{2}$ These strategies are designed to bet against extrapolative strategies that are based upon past earnings, dividends, and other measures of a firm's performance. Lakonishok, Shleifer, and Vishny argue that these strategies work because securities markets contain important institutional failures. For example, institutional investors may pick stocks with a history of good earnings because these are easy to justify to clients, or investors are afraid of being wrong, so they choose the same stocks as everyone else. In this case, the financial markets would be quite inefficient and subject to important short-horizon influences on the part of institutional investors. Furthermore, this type of short-horizon effect could only be captured using lagged stock prices and earnings directly.

The view that deviations from the CAPM reflect important market inefficiency is certainly not uniform. For example, Eugene Fama and Kenneth French interpret the influence of variables such as book value-tomarket value on excess returns as reflecting variation in systematic risk. ${ }^{3}$ In fact, the variables that affect the discount factors in Hall and Hall's regressions could be driving, or reflecting, differences in systematic risk not captured by their risk correction. It would be interesting to determine whether the variables that Hall and Hall are using have additional explanatory power over and above book value-to-market value or size, for example. This would help to shed some more light on this debate in the finance literature.

In general, any inefficient markets or short horizons interpretation of the rejection of a particular asset pricing model is open to the criticism that the problem could be that the model under the null hypothesis is too simple. For example, Hall and Hall assume that risk premia are constant over time. As long as the stocks that Hall and Hall consider do not admit pure arbitrage (a violation of the law of one price), then there is a stochastic discount factor such that stock prices are given by the present

2. Lakonishok, Shleifer, and Vishny (1993).

3. Fama and French (1992). 
discounted value of future dividends and the terminal stock price used by the authors. Although Hall and Hall argue that the excess discounting is declining over time, they need to consider whether arbitragers could really have used their explanatory variables to make relatively risk-free returns. If arbitragers faced significant risk in exploiting these results, then Hall and Hall could simply be picking up variations in systematic risk, and not the horizons of individual investors.

Regardless of the problem of interpreting the rejections of any simple model, Hall and Hall conclude that there is evidence against investor myopia and if anything, this myopia is disappearing over time. Based upon my priors and their evidence, in the end, I agree with this conclusion. Also I find the authors' approach of using a very large cross-section of firms and of using variables other than financial variables to explain differences in returns to be very interesting and important.

However, if I were a proponent of the view that American capitalism suffers from myopia induced by informational problems, I would not be convinced by these results. This is because financial markets can be perfectly efficient in the sense that stock prices are the discounted value of future dividends, but the dividend or earnings streams of firms could be distorted. This point has been made by Jeremy Stein. ${ }^{4}$

Stein argues that managers have better information about the future payoff of investments than do investors and that some correlation in earnings occurs over time. Further, managers care about the current stock price because they are worried about takeover attempts, for example. In this setting, managers have an incentive to try to manipulate current earnings to try to fool investors into believing that the firm is strong. For example, they may try to exploit current market share to the detriment of long-term profit to try to boost earnings. Investors are not fooled by this, however. Investors predict the future course of earnings knowing that the managers will play games. The stock price is given by the discounted value of expected dividends where the expectations are correct in equilibrium. In this world, managers make inefficient choices and everyone is worse off because of the focus on current stock price. However, the stock price is the discounted value of future dividends. The problem is that efficient capital markets can coexist with inefficient decisions by firms. Notice that the economic problem is not caused by the

\section{Stein (1989).}


fact that managers are reacting to bad market signals that can be detected by looking at stock market returns.

Hall and Hall recognize that this is a potential limitation to focusing on stock market inefficiency. However, I think that it must be emphasized that tests of the efficiency of capital markets may have limited scope in evaluating the economic significance of the short horizons of U.S. investors.

N. Gregory Mankiw: There is a common perception that U.S. corporations are in some sense short-sighted: that managers frequently forgo profitable opportunities because the benefits occur too far in the future. I have always been skeptical of this view because those espousing it rarely provide much hard evidence. This paper by Bronwyn Hall and Robert Hall is a welcome relief. The paper attempts to use the tools of modern financial economics to address empirically this issue of corporate myopia. This effort is a timely one because some in the Clinton administration seem prone to policies aimed at correcting this alleged market failure.

One can view this work as addressing the age-old question, "If you're so smart, why aren't you rich?" Rarely in life is this smart-alecky retort appropriate, but in this case it is. If firms are short-sighted, then somewhere there should be money to be made. Those who assert that firms are failing to maximize profits should be able to give us a prescription for creating wealth.

This paper looks for such profit opportunities in the stock market. If managers maximize current shareholder value, then business decisions will reflect stock market valuations. In this case, myopic decisionmaking implies that stock market valuations are incorrect.

Note, however, that incorrect pricing of firms by the stock market is, as a logical matter, neither necessary nor sufficient for myopic management. One can imagine a world in which the stock market values firms correctly, yet managers nevertheless choose strategies that raise earnings in the short run at the expense of the long run. Managers might choose this course because high current earnings would fund more perquisites, such as corporate jets and lavish offices. In this world, managers fail to maximize shareholder value. The only way to make money is to take over the firms and throw out the managers. This strategy made a few people a lot of money in the 1980s. 
Alternatively, one can imagine a world in which the stock market values firms incorrectly, yet managers nonetheless make the appropriate investment decisions. In this case, managers also fail to maximize current shareholder value, but they are maximizing the value of a shareholder who holds the shares for the long term. The way to make money in this world is to buy stocks that are currently underpriced. I will discuss how to do that in a moment.

Despite these two hypothetical cases, I think it is fair to assume that incorrect pricing by the stock market and inappropriate decisionmaking by management probably go together. Managers' compensation is often based on the near-term share prices of their firms. If the stock market values firms correctly, only an incompetent manager would fail to maximize the market's valuation. And if the stock market values firms incorrectly, only an exceptionally scrupulous manager would ignore market signals. It is safe to assume that neither case is the norm.

For this reason, it is natural to look for valuation mistakes by the stock market as a test of corporate myopia. The primary empirical conclusion in this paper is that the stock market makes systematic mistakes that are related to observable firm characteristics, such as investment in plant and equipment.

This finding is closely related to a large literature in financial economics showing that one can predict the excess returns on individual stocks. ${ }^{1}$ The right investment strategy is very simple: buy stocks whose price is low relative to fundamentals. What is striking about this literature is that fundamentals can be measured in any of a variety of ways: book value, earnings, cash flow, or dividends. Each of these strategies works when considered by itself, and they work even better in combination. The estimated size of the excess returns is large-indeed, larger than those reported in this paper. Picking out-of-favor stocks using any of these rules produces excess return of about 2 to 3 percent per year over at least five years.

Another variable that seems to forecast excess returns in stock prices is growth in sales. Stocks of firms that have experienced low growth in sales over the past five years tend subsequently to produce higher returns. This strategy works when considered by itself, and it works after controlling for price-earnings ratios. When reading this paper, I won-

1. One of the early papers in this literature is Basu (1977). For more recent work, see Fama and French (1992) and Lakonishok, Shleifer, and Vishny (1993). 
dered whether the Halls' cross-sectional regressions are picking up this effect. It seems possible that the investment rate is proxying for growth in sales: low-growth firms probably tend to have low rates of investment as well.

The simplest way to explain all these results is to appeal to some form of market irrationality. If stock prices fluctuate because of fads or animal spirits, then price-earnings ratios will proxy for the degree of mispricing. Moreover, if investors tend to extrapolate past performance more than they should, then past growth might also be a good proxy.

Note that neither fads nor excessive extrapolation of past growth is exactly the same as myopia or excessive discounting. There are a variety of ways for stock prices to be irrational, and they are fundamentally different. We economists have spent so long studying rational behavior that we are not very good at talking about irrationality. Irrational behavior is a much harder problem. In most environments, there is only one way to act rationally, but many ways to act irrationally.

Another possibility is that some statistical or data problem has yet to be uncovered that will discredit all this evidence. I take this possibility seriously because that has been the fate of many past rejections of the efficient markets hypothesis. About a decade ago, Robert Shiller's pioneering work on volatility tests seemed to make a convincing case that stock and bond markets were much too volatile. ${ }^{2}$ Yet subsequent work, by Marjorie Flavin and others, showed some serious flaws in Shiller's approach. ${ }^{3}$ More recently, papers by Eugene F. Fama and Kenneth R. French ${ }^{4}$ and by James M. Poterba and Lawrence H. Summers ${ }^{5}$ have argued that aggregate stock prices exhibit long-term mean reversion. Yet even more recent work by Myung Jig Kim, Charles A. Nelson, and Richard Startz has convinced me that the evidence for mean reversion is so far from statistical significance that it is not worth taking seriously. ${ }^{6}$

In this paper by Hall and Hall, one troubling aspect of the methodology is the computation of standard errors. The standard errors are based on the assumption that the covariances among different stock returns can be captured by adding time dummies to the panel regression.

2. Shiller (1981).

3. Flavin (1983).

4. Fama and French (1988).

5. Poterba and Summers (1988).

6. Kim, Nelson, and Startz (1991). See also the Monte Carlo results in table 7 of Mankiw, Romer, and Shapiro (1991). 
Clearly, however, the actual variance-covariance matrix is more complex. At the very least, we know that stocks have different betas; that is, they respond differently to aggregate shocks to the market. Moreover, there are industry effects that make individual stocks fluctuate together in a way not captured by time dummies.

I fear that correct standard errors could leave the results in this paper insignificant. In a recent paper, Josef Lakonishok, Andrei Shleifer, and Robert W. Vishny test for the success of contrarian investment strategies, such as buying stocks with low price-earnings ratios. ${ }^{7}$ They compute standard errors using a procedure that is more robust to crosssectional correlations. Although the predicted excess returns they find are larger than those reported in this paper, most of their $t$ statistics are only a little above two.

Nonetheless, I expect the general finding of this literature-that excess returns can be forecast with known information-to hold up under closer scrutiny. I have several reasons to believe this. First, the crosssectional evidence is consistent with the time-series evidence. According to the time-series evidence, when the aggregate price-earnings ratio is high, as it is today, subsequent stock returns will be low. ${ }^{8} \mathrm{Sec}-$ ond, the success of contrarian investment strategies has been shown to work in other countries. It works even in Japan, where myopia is not supposed to be a problem. ${ }^{9}$ Third, the findings of predictable excess returns have continued long after they have been noticed. In 1971, Fischer Black wrote a paper in which he reluctantly concluded that following the recommendations of Value Line produces significant excess returns. ${ }^{10}$ Value Line makes its recommendations using a complex strategy based largely on trends in price-earnings ratios. Since Black wrote this article, Value Line's recommended stocks have continued to outperform the market, suggesting that there is more to Value Line's system than mere luck. ${ }^{11}$

7. Lakonishok, Shleifer, and Vishny (1993).

8. Campbell and Shiller (1988).

9. Chan, Hamao, and Lakonishok (1991).

10. Black (1971).

11. The simple strategy of buying stocks with low price-earnings ratios has also continued to work well. See John A. Dorfman, "Which Stock Picking Strategies Work Best in a Turbulent Market?" Wall Street Journal, May 20, 1993, p. C1. That article notes that such stocks outperformed the S\&P 500 by 7.4 percent in the first four months of 1993 and by 42.4 percent in the six years from 1987 to 1992. 
Let me now turn from evidence to interpretation. If we conclude that the stock market values firms incorrectly, what does this finding imply for public policy?

Let's take a concrete example. Right now, Martin Marietta is selling for 10 times earnings and Lockheed is selling for 11 times earnings. By contrast, Intel is selling for 23 times earnings, and Microsoft is selling for 31 times earnings. What does this literature tell us to do? From these price-earnings ratios we can infer that the market is excessively pessimistic about defense stocks and excessively optimistic about civilian high-tech stocks. Clearly, we should buy Martin Marietta and Lockheed and sell short Intel and Microsoft.

The advice for policy is also clear. The irrational market is placing too high a premium on resources in civilian high-tech firms relative to defense firms. If managers are responding to these market signals, as they probably are, then they are excessively moving resources from defense to civilian high tech. Put simply, the right policy is to impede defense conversion.

Of course, I do not offer this advice seriously. It is noteworthy, however, that the Clinton administration is pursuing exactly the opposite policy. When the administration says that we need a technology policy, it is saying that the unfettered market is not sufficiently enthusiastic about high technology, despite high price-earning ratios for the firms in this industry.

Whenever one is told that any market allocates resources inefficiently, the correct response is, "Compared to what?" I am prepared to believe that there is some noise in stock prices. Some investors are subject to fads, irrational extrapolation, and myopia. Rational investors may not be sufficiently numerous to insulate market prices from the irrational ones. But before I accept the existence of some correctable market failure, I must be persuaded that government policy is less faddish and more farsighted than the market. The government is not run by omniscient social planners. It is run by bureaucrats who, unlike private investors, have little personal stake in whether their policies succeed or fail. Within four years, many of these bureaucrats will return to comfortable tenured jobs in academia. To paraphrase Lloyd Bentsen, I know these bureaucrats, I have worked with these bureaucrats, these bureaucrats are friends of mine, and I would rather bet my money on the rationality of the stock market. 


\section{General Discussion}

Several participants suggested that the relationship between firm characteristics and the discount rate could reflect correlation between those characteristics and risk. Bronwyn Hall agreed to that possibility, noting that the paper was not about arbitrage possibilities in the stock market, but rather about the effect of firms' fundamentals on the stock price. She acknowledged that including market betas or other measures of risk would sharpen the interpretation of the paper's results, possibly distinguishing between the effects of risk and other factors on the discount rate. James Tobin suggested including what he called a fundamental beta, which would measure the covariance of firm earnings with market earnings. Andrei Shleifer suggested that the covariance of firm cash flow with market cash flow would be a better measure than earnings because book earnings are subject to substantial manipulation. Robert Hall observed that to be truly fundamental would require using the covariance of dividends with consumption, but consumption betas did not typically perform well. William Brainard hazarded a guess based on earlier work that none of a wide variety of betas would explain very much of the differences in a firm's risk premiums in panel data.

Olivier Blanchard argued that differences in the R\&D-asset or investment-asset ratios were probably better indicators of differences in risk than differences in beta coefficients. If these variables continued to be significant even after controlling for betas, he would still be inclined to interpret their importance as information about riskiness. Andrei Shleifer disagreed; he was skeptical about interpreting differences in implicit discount rates as reflecting differences in risk. He believed that out-of-favor stocks, with low market valuations relative to future earnings and dividends, do not typically have higher betas or risk by any other sensible measure. In his view, some observers come close to making the explanation of market values tautological; in effect, the prediction of excess returns is taken as the measure of risk. Blanchard responded that it is possible to avoid this extreme view while still arguing that particular characteristics, such as the ratio of R\&D to assets, are associated with the stochastic features of the earnings profile of a firm.

Richard Cooper asked how the results are affected by investors who buy and hold stocks even when they expect no dividends. Robert Hall 
explained that the paper's measure of returns treats the market value at the end of the sample period, or when the firm is taken over or liquidated, as a terminal dividend. Brainard observed that this treatment precluded distinguishing between the market valuation of capital gains and dividends. Robert Hall defended the use of the actual terminal price, arguing that it avoided the problems encountered by Robert Shiller in synthesizing prices into the future. The method gave firms further from their terminal dates the most leverage in the regressions, reflecting the greater information content of these observations.

Clark wondered whether changing the terminal date would have a large effect on the results. Bronwyn Hall suggested that the major consequence would likely to be a change in the average risk premium, but that the estimated effects of individual firm characteristics would be less likely to change. Anything that affects all firms in the cross section more or less equally, such as the 1987 crash, would not alter their results.

Shleifer saw the key issue of the paper as being whether firms invest in response to their valuation by the stock market. He was surprised by the paper's framework, which assumed that managers took account of stock valuation, rather than their own perception of future profits, in making investment decisions. He referred to work by Robert Vishny and himself which found that, controlling for future prospects of the firm using variables other than stock market valuations, the stock market had little effect on investment. Robert Hall responded that the paper was not about how managers actually decide on investment, but rather about how the market values what they deliver to their shareholders in the way of returns. The paper was not about corporate myopia, but rather about stock market myopia.

Tobin observed that some of the assets of a firm are financed by debt rather than equity, so that any attempt at valuing the visible assets of the firm should take into consideration the value of the debt. Hence it would have been desirable to study the dependence of the total market value of the firm on firm characteristics. Robert Hall, while acknowledging the feasibility of taking debt into account, felt that debt markets do not respond to news in the same way as stock markets; hence it would be necessary to distinguish the nature of the claims that bonds and stocks represent.

William Nordhaus noted that the firm observations were unweighted by firm size. He observed that in order to draw implications for Ameri- 
can capitalism, as was suggested in the paper, the firms' characteristics would have to be weighted by firm size in order to judge the importance of any under- or overvaluation. Nordhaus further observed that the puzzles of excess returns raised by the paper were not restricted to U.S. stock markets. Excess returns have been found in other markets for risky assets in the United States, as well as in stock markets in other parts of the world. Hall affirmed that U.S. capitalism was by no means unique in this respect. 


\section{References}

Amemiya, Takeshi. 1974. "The Nonlinear Two-Stage Least-Squares Estimator." Journal of Econometrics 2(2):105-10.

$\rightarrow$ Basu, S. 1977. "Investment Performance of Common Stocks in Relation to their Price-Earnings Ratios: A Test of the Efficient Market Hypothesis." Journal of Finance 32(3):663-82.

Black, Fischer. 1971. "Yes, Virginia, There Is Hope: Tests of the Value Line Ranking Service." How to Use the Value Line Investment Survey: A Subscriber's Guide. Reprint. From a paper presented at the Center for Research on Security Prices. Chicago: University of Chicago (May).

Bound, John, and others. 1984. "Who Does R\&D and Who Patents?" In $R \& D$, Patents, and Productivity, edited by Zvi Griliches. Chicago: University of Chicago Press.

Brainard, William C., Matthew D. Shapiro, and John B. Shoven. 1991. "Fundamental Value and Market Value." In Money, Macroeconomics, and Economic Policy: Essays in Honor of James Tobin, edited by William Brainard, William Nordhaus, and Harold H. Watts. Cambridge, Mass.: MIT Press.

Brainard, William C., John B. Shoven, and Laurence Weiss. 1980. "The Financial Valuation of the Return to Capital." BPEA, 2:1980, 453-502.

$\rightarrow$ Campbell, John Y., and Robert J. Shiller. 1988. "Stock Prices, Earnings, and Expected Dividends." Journal of Finance 43(3):661-76.

$\rightarrow$ Chan, Louis K.L., Yasushi Hamao, and Josef Lakonishok. 1991. "Fundamentals and Stock Returns in Japan." Journal of Finance 46(5):1739-64.

Cochrane, John H. 1991. "Volatility Tests and Efficient Markets: A Review Essay." Journal of Monetary Economics 27(3):463-85.

Cochrane, John H., and Lars Peter Hansen. 1992. "Asset Pricing Explorations for Macroeconomics." In NBER Macroeconomics Annual 1992, edited by Olivier Jean Blanchard and Stanley Fischer. Cambridge, Mass.: MIT Press.

Coleman, Thomas S., Lawrence Fisher, and Roger G. Ibbotson. 1989. U.S. Treasury Yield Curves 1926-1988. New York: Moody's Investors Service.

$\rightarrow$ De Bondt, Werner F. M., and Richard Thaler. 1985. "Does the Stock Market Overreact?" Journal of Finance 40(3):793-805.

Durlauf, Steven N., and Robert E. Hall. 1990. "Bounds on the Variances of Specification Errors in Models with Expectations." Unpublished paper. Stanford University (November).

Fama, Eugene F., and Kenneth R. French. 1988. "Dividend Yields and Expected Stock Returns." Journal of Financial Economics 22(1):3-25.

$\longrightarrow \rightarrow$ 1992. "The Cross-Section of Expected Stock Returns." Journal of Finance 46(2):427-66.

Farb, Warren E. 1993. "An International Comparison of Investment Behavior As a Key to the Time Horizons of American Industry." In Capital Choices: Changing the Way America Invests in Industry, edited by Michael E. Porter. Boston: Harvard Business School Press (forthcoming). 
$\rightarrow$ Flavin, Marjorie. 1983. "Excess Volatility in Financial Markets: A Reassessment of the Empirical Evidence." Journal of Political Economy 91(6):92956.

Friedman, Milton. 1957. A Theory of the Consumption Function. Princeton, N.J.: Princeton University Press.

Froot, Kenneth A., Andre F. Perold, and Jeremy C. Stein. 1993. "Shareholder Trading Practices and Corporate Investment Horizons. In Capital Choices: Changing the Way America Invests in Industry, edited by Michael E. Porter. Boston: Harvard Business School Press (forthcoming).

$\rightarrow$ Gilles, Christian, and Stephen F. LeRoy. 1991. "Econometric Aspects of the Variance-Bounds Tests: A Survey." The Review of Financial Studies 4(4):753-91.

$\rightarrow$ Grossman, Sanford J., and Robert J. Shiller. 1981. "The Determinants of the Variability of Stock Market Prices." American Economic Review, Papers and Proceedings 71(2):222-27.

Hall, Bronwyn H. 1990. "The Manufacturing Sector Master File." Working Paper 3366. Cambridge, Mass.: National Bureau of Economic Research (May).

- 1992. "The Value of Intangible Corporate Assets: An Empirical Study of the Components of Tobin's $q$." Unpublished paper. University of California at Berkeley (December).

$\rightarrow-$. 1993a. "The Stock Market Value of R\&D Investment During the 1980s." American Economic Review 83:259-64.

- 1993b. "Corporate Restructuring and Investment Horizons." In Capital Choices: Changing the Way America Invests in Industry, edited by Michael E. Porter. Boston: Harvard Business School Press (forthcoming).

and others. 1988. "The R\&D Master File: Documentation." Technical Working Paper 72. Cambridge, Mass.: National Bureau of Economic Research.

Hall, Robert E. 1980a. "Employment Fluctuations and Wage Rigidity." BPEA, 1:1980,91-123.

- 1980b. "Comment on 'The Financial Valuation of the Return to Capital.' "BPEA, 2:1980, 506-8.

$\rightarrow$ Hansen, Lars Peter, and Ravi Jagannathan. 1991. "Implications of Security Market Data for Models of Dynamic Economies." Journal of Political Economy 99(2):225-62.

Jensen, Michael. 1988. "The Takeover Controversy: Analysis and Evidence." In The Impact of the Hostile Takeover, edited by John C. Coffee, Jr., and Louis Lowenstein. New York: Oxford University Press.

$\rightarrow$ Kim, Myung Jig, Charles R. Nelson, and Richard Startz. 1991. "Mean Reversion in Stock Prices? A Reappraisal of the Empirical Evidence." Review of Economic Studies 58(3):515-28.

Lakonishok, Josef, Andrei Shleifer, and Robert W. Vishny. 1993. "Contrarian Investment, Extrapolation, and Risk." Unpublished paper. University of Illinois (March). 
$\rightarrow$ LeRoy, Stephen F., and Richard D. Porter. 1981. "The Present Value Relation: Tests Based on Implied Variance Bounds." Econometrica 49(3):555-74.

Malkiel, Burton G. 1993. "The Influence of Conditions in Financial Markets on the Time Horizons of Business Managers: An International Comparison." In Capital Choices: Changing the Way America Invests in Industry, edited by Michael E. Porter. Boston: Harvard Business School Press (forthcoming).

$\rightarrow$ Mankiw, N. Gregory, David Romer, and Matthew D. Shapiro. 1991. "Stock Market Forecastability and Volatility: A Statistical Appraisal." Review of Economic Studies 58(3):455-77.

$\rightarrow$ Mankiw, N. Gregory, and Matthew D. Shapiro. 1986. "Risk and Return: Consumption Beta versus Market Beta." Review of Economics and Statistics 68(3):452-9.

McConnell, John J., and Chris J. Muscarella. 1985. "Corporate Capital Expenditure Decisions and the Market Value of the Firm." Journal of Financial Economics 14 (3):399-422.

$\rightarrow$ Mehra, Rajnish, and Edward C. Prescott. 1985. "The Equity Premium: A Puzzle." Journal of Monetary Economics 15(2):145-61.

Porter, Michael. 1992. Capital Choices: Changing the Way America Invests in Industry. Washington: Council on Competitiveness.

Poterba, James M., and Lawrence H. Summers. 1988. "Mean Reversion in Stock Prices." Journal of Financial Economics 22(1):27-59.

. 1993. "Time Horizons of American Firms: New Evidence from a Survey of CEOs." In Capital Choices: Changing the Way America Invests in Industry, edited by Michael E. Porter. Boston: Harvard Business School Press (forthcoming).

$\rightarrow$ Scott, Louis O. 1985. "The Present Value Model of Stock Prices: Regression Tests and Monte Carlo Results." Review of Economics and Statistics 64(4):599-605.

$\rightarrow$ Shiller, Robert J. 1981. "Do Stock Prices Move Too Much to Be Justified by Subsequent Changes in Dividends?" American Economic Review 71(3):421-36.

Startz, Richard. 1982. "Do Forecast Errors or Term Premia Really Make the Difference between Long and Short Rates?" Journal of Financial Economics 10(3):323-9.

$\rightarrow$ Stein, Jeremy C. 1989. "Efficient Capital Markets, Inefficient Firms: A Model of Myopic Corporate Behavior." Quarterly Journal of Economics 104(4):65569. 